\title{
NEW CULTIVARS
}

Keywords: cultivar: Sarracenia 'Purple Velvet', Dionaea muscipula 'Gremlin', Dionaea muscipula 'Ginormous', Nepenthes 'The Succubus'

\section{Sarracenia 'Purple Velvet'}

Submitted: 10 December 2012

I developed a new hybrid, Sarracenia 'Purple Velvet', by transferring the pollen from a tall dark red $S$. alata $\times$ willisii to the ovary of a $S$. purpurea subsp. venosa. The pollination occurred in October 2006. Six seeds were collected and sown in May 2007 and sprouted in October 2007. While two of the seedlings raised from the same ovary have similar shaped pitchers, one of the plants is veined, green in color and larger in size (Fig. 1 left), whereas the second plant, Sarracenia 'Purple Velvet' (Fig. 1 right), is smaller and has characteristics unique to any other Sarracenia purpurea hybrid I have come across. Sarracenia 'Purple Velvet' produces decumbent pitchers that are similar in shape to $S$. purpurea subsp. venosa, although these are slightly thinner, pitchers are dark purple, and the lid curves inwards. New pitchers are dark red in color, before intensifying into a dark purple color as the pitcher matures. Downward pointing hairs are present on the inner surface of the lid, as with the $S$. purpurea parent. The pitchers are currently $19 \mathrm{~cm}$ in height (including the lid) and $3 \mathrm{~cm}$ in width (6 $\mathrm{cm}$ across the lid). Characteristics inherited from the pollen parent include slightly thinner pitchers and their dark color. I coined the name Sarracenia 'Purple Velvet' on 27 January 2012 due to its intense purple color. This plant has so far not flowered, although both parent plants have the same red colored petals.

-Steve Amoroso • Australia • steve.1600@yahoo.com
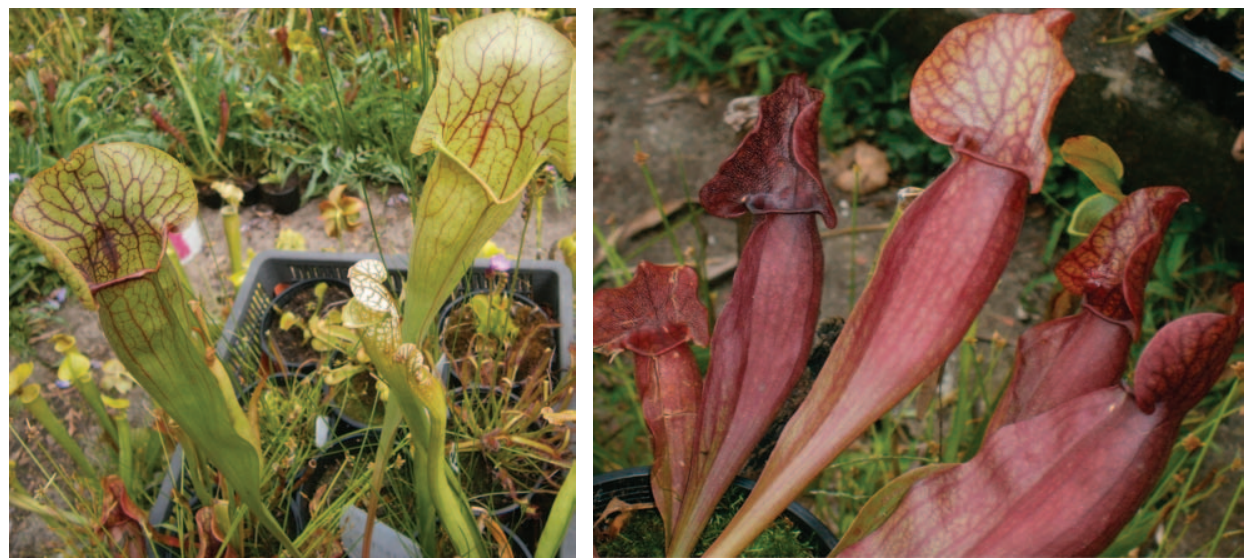

Figure 1: Sibling of Sarracenia 'Purple Velvet' (left) and Sarracenia 'Purple Velvet' (right).

\section{Dionaea muscipula 'Gremlin'}

Submitted: 23 October 2012

Occasionally when we have been low on Venus' flytraps, we purchase them from a large wholesaler that usually puts them in horrible little capsules and sends them to the slaughter at local big 
box stores. In May 2009, I found a nice all green form in one of the batches. I liked the look of it and as I didn't have an all-green flytrap in my personal collection, I brought it home and grew it outdoors with my other flytraps. By September 8, it had stuffed the pot so that the sides were bulging out (Fig. 2).

That winter I divided the plant and put it into a $30-\mathrm{cm}$ bowl, which it promptly filled with plants. The next year, the plants easily filled up two such $30-\mathrm{cm}$ bowls with some extra.

As I looked at the mound of plants that resulted in just a few years from a small clump, I realized that this plant was something special. Clearly this is an extremely vigorous clone that has a bizarre obsession with freely dividing and clumping. All you need to do is apply plenty of distilled water,
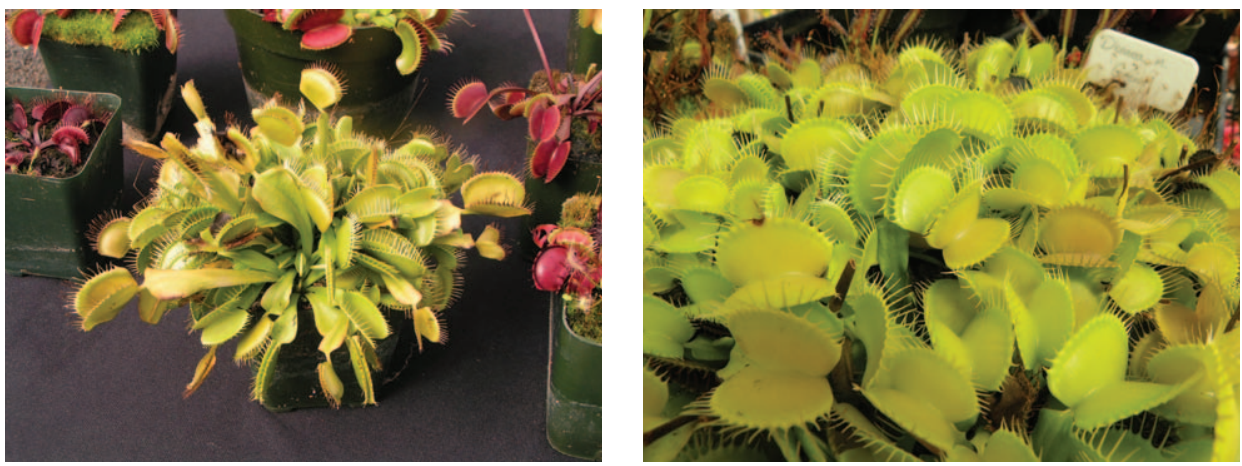

Figure 2: Dionaea 'Gremlin' fills a 30-cm bowl.

then sit back and watch it multiply like a gremlin. While the plant is entirely golden green, new traps may blush a very light pink when they first open in strong light. This fades away to green as they mature, but, because of this, I doubt that it is truly anthocyanin free. It can be distinguished from 'Justina Davis' by the pink blush in newly opened traps and its vigorous clumping nature.

This clone will soon be in tissue culture. We have sold a precious few in the nursery this year, but we are hoping to have many more next summer.

Warning! Do not feed after midnight...

-Damon Collingsworth • California Carnivores • 2833 Old Gravenstein Hwy • Sebastopol, CA 95472・Califcarn@aol.com

\section{Dionaea muscipula 'Ginormous'}

Submitted: 23 October 2012

Peter D'Amato first wrote about visiting the introduced carnivorous plant bogs at Albion, California in 1988 in his article, "A Field Trip to Mendocino" Carniv. Pl. Newslett. 17(1):1519,21 and he took me there for the first time in 2005. On the long drive to Mendocino County, Peter told me of the large clump of Venus' flytraps that he had visited for years.

After we had explored the area for quite a while, Peter pointed and as my gaze followed his direction I saw the familiar white flytrap flowers sticking up out of the grass. I hurried to see it closer and was rewarded with a view of a massive flytrap clump. The traps were so huge that a few of them had even trapped little Pacific tree frogs (Fig. 3). All that remained were tiny, skeletonized shadows pressed into one side of the trap. Amazing! 
This was the first "wild" flytrap that I had ever seen, so I attributed its large size to its age, habitat, and gruesome diet. Now, years later, after visiting many flytrap sites in North Carolina, I realize that it would have been the biggest flytrap in any bog.

As time went by, I visited the Albion bog almost every year to check in and take photos. Then just a few years ago, we found out that the property was owned by The Nature Conservancy (TNC), and that TNC did not appreciate the planting of non-native plants on their property. Barry Rice, then employed by TNC, participated in a removal of the flytraps along with a few other introduced carnivores, and the plants were donated to University of California, Berkeley. Dionaea muscipula 'Ginormous' is a division from that plant that used to grow in Albion.

Once, I got my hands on a piece of this old friend, I grew it outdoors at home with my other flytraps and by the end of that summer it had grown remarkably large again! Now, after growing it for a few years, I have realized that it is possibly the biggest and best flytrap cultivar so far, producing traps that rival those of the now famous and mighty Dionaea 'B52' (Fig. 3,
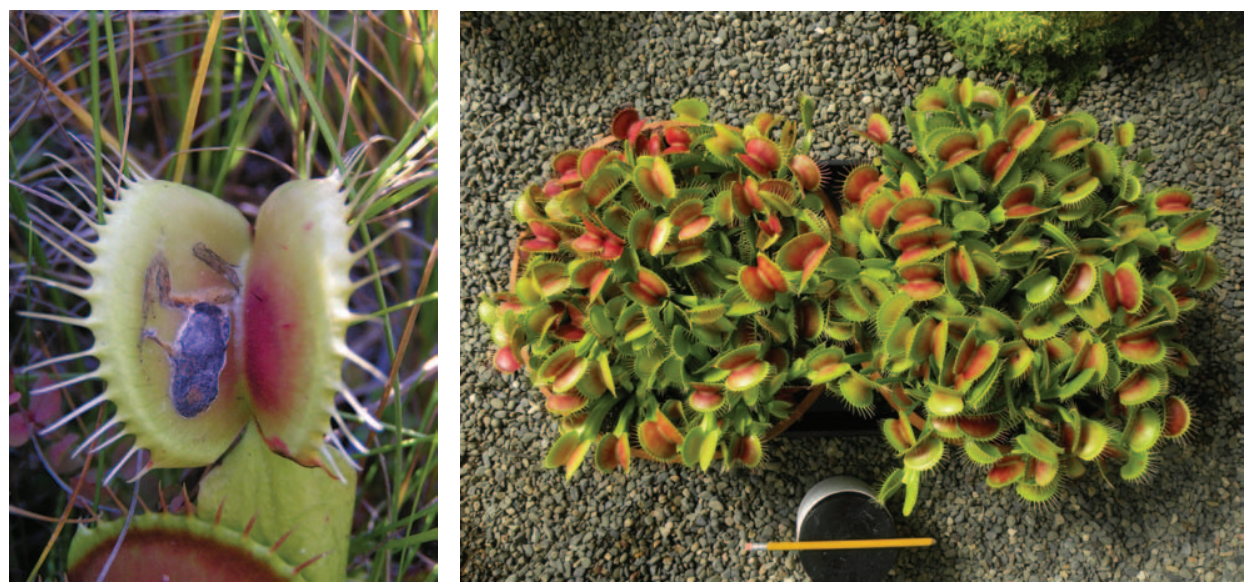

Figure 3: Dionaea 'Ginormous' with a tree frog (left) and comparison of Dionaea 'B52' (rightleft) and Dionaea 'Ginormous' (right-right).
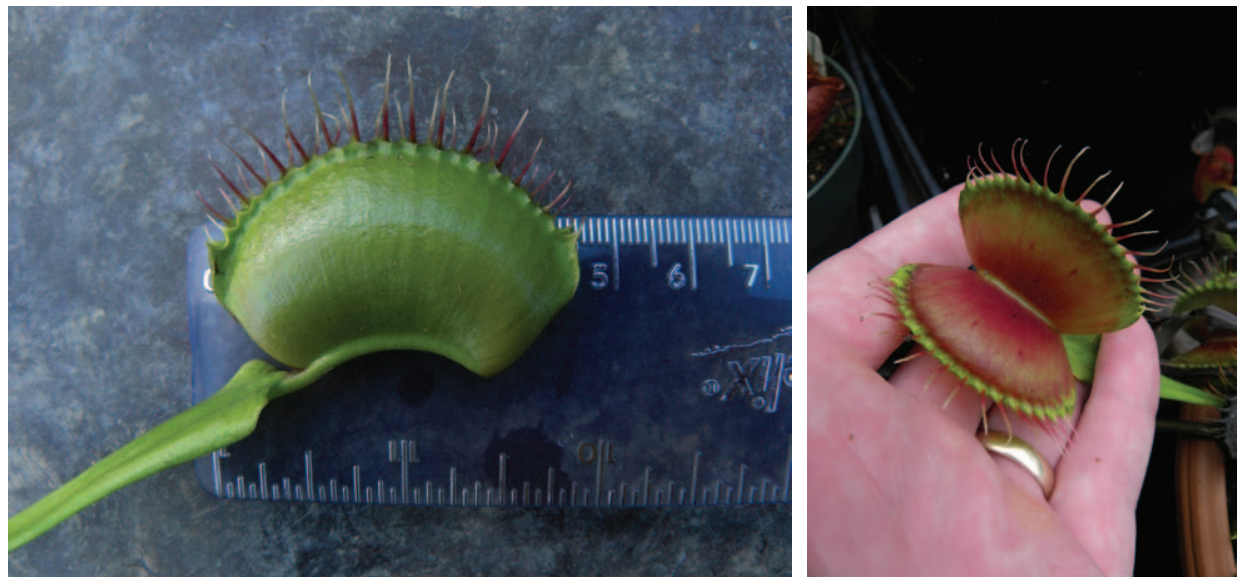

Figure 4: The traps of Dionaea 'Ginormous' can be $4.5 \mathrm{~cm}$. 
4, Back Cover). It seems to be slightly more vigorous than 'B52' especially when grown outdoors. It can also be distinguished from that clone because the petioles tend to be longer and the interiors of the traps are very red, but often not quite as dark red as 'B52'. I am quite sure that it is not 'B-52', as this flytrap had been there in Albion since at least 1988, long before 'B-52' was even a glimmer in Henning von Schmeling's eye.

I have asked those who originally planted carnivorous plants in the bog (who shall remain nameless) about the flytrap and no one quite remembers who put what where. It may be that this is some old unregistered clone long forgotten, but I doubt it. It seems to me that if a cultivar of this quality had been around years ago, surely it would be well known and distributed by now.

We recently introduced 'Ginormous' into tissue culture and we should have large quantities for sale exclusively at California Carnivores by summer 2013. Also, in an effort to breed ever larger traps, we have also crossed 'Ginormous' with 'B52' and the progeny already have giant traps for their age. These should be available by next spring too.

Postscript: California Carnivores would never condone feeding poor little frogs to flytraps. Frogs are our friends!

-Damon Collingsworth • California Carnivores • 2833 Old Gravenstein Hwy • Sebastopol, CA 95472•Califcarn@aol.com

Nepenthes 'The Succubus'

Submitted: 1 October 2012

Nepenthes 'The Succubus' is a hybrid N. lowii $\times$ ventricosa (red form) that was produced by Geoff and Andrea Mansell of Exotica Plants, Australia, and purchased as a small cutting in 2007 from Tony Paroubek at Exotic Plants Plus, USA.

The characteristics that distinguish $N$. 'The Succubus' from a somewhat similar cultivar $N$. 'Peter D'Amato' are that $N$. 'The Succubus' has exaggerated features of the pitcher mouth with a flaring peristome (Fig. 5), and larger peristome teeth with the pitcher lid consistently exhibiting numerous hairy spikes (Fig. 6) The pitcher body is squat, robust, and bulbous. The pitcher coloration is deep red, even the tendril and pitcher base are richly colored a uniform red. The upper pitchers are still quite deeply colored and have great peristome striping, with deep reds and flushed yellows.

The pitchers of $N$. 'Peter D'Amato' tend to be longer and more slender and do not have the consistent, full lid of hairy spikes nor as large peristome teeth. The parents of $N$. 'Peter D'Amato', according to The Savage Garden (D'Amato 1998 p.274), are N. ventricosa $\times$ lowii.

The female $N$. lowi $\times$ male $N$. ventricosa cross (note that the female and male parents are reversed) that produced $N$. 'The Succubus' gives this cultivar stronger $N$. lowii characteristics such as the lid spikes, peristome teeth, and more contorted features, but making it less tolerant of warm temperatures and not as fast growing. The deep coloration, numerous lid spikes and striped peristome, even on the upper pitchers, are all distinguishing characteristics that set this individual apart from other $N$. lowii $\times$ ventricosa hybrids.

Also, the plant grows large like $N$. lowii, compact like $N$. ventricosa, and produces pitchers frequently, making it a great indoor specimen (Fig. 7). It grows well in warm temperatures, but exhibits the best characteristics in cooler temperatures akin to the $N$. lowii parent. 

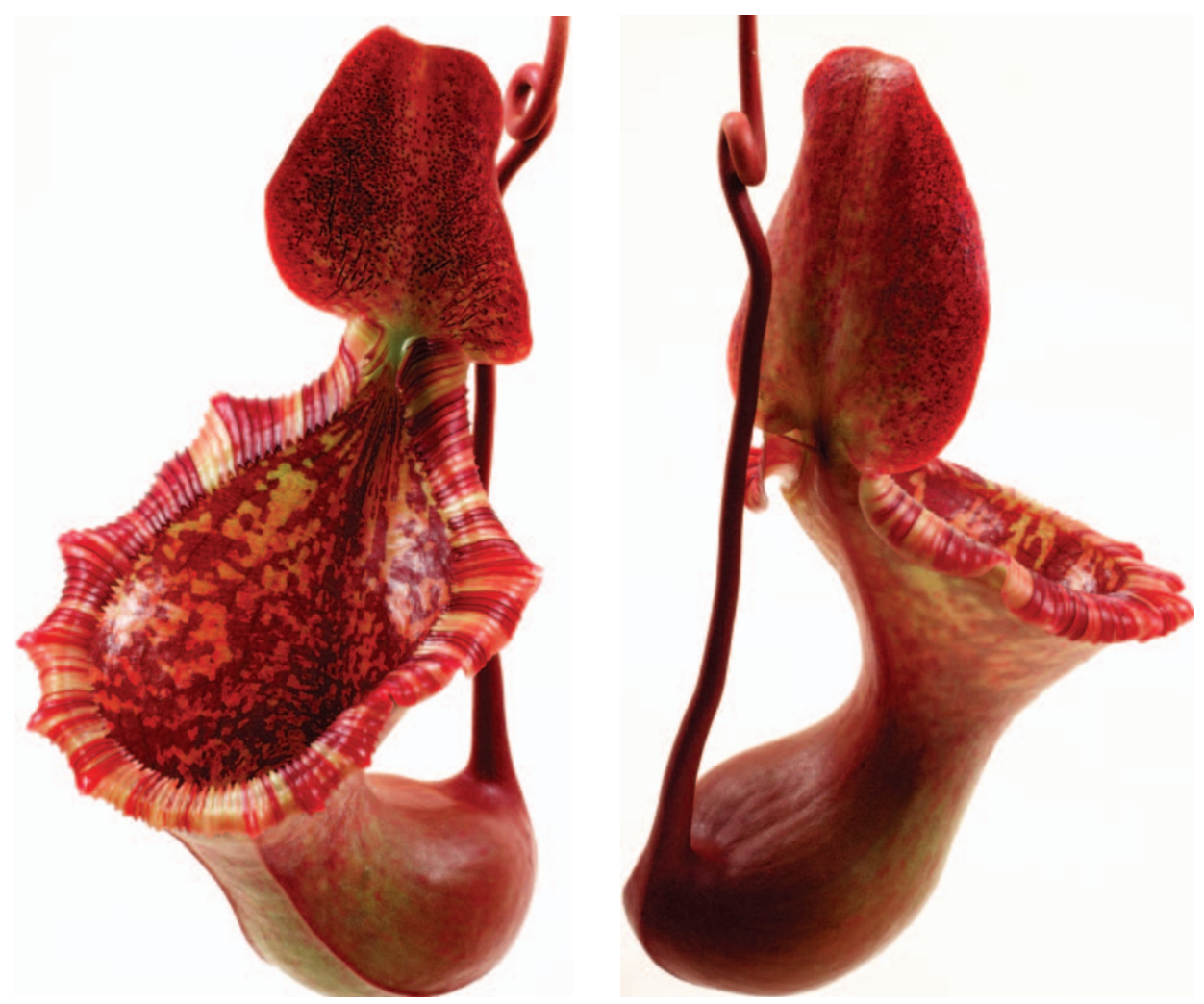

Figure 5: Nepenthes 'The Succubus' pitcher.
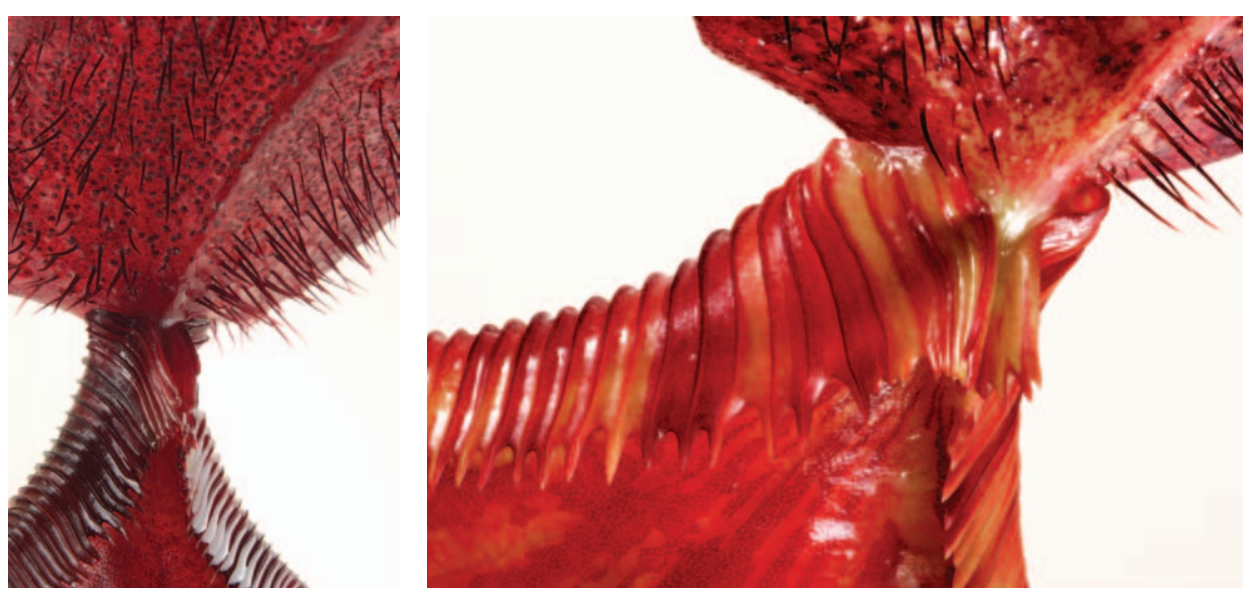

Figure 6: Nepenthes 'The Succubus' lid with numerous hairs (left) and peristome teeth (right).

The plant has flowered and is a female.

This plant was awarded Juried Best-in-Show at the 2012 ICPS Conference and Best-in-Show at the 2010 NECPS Exhibition. 


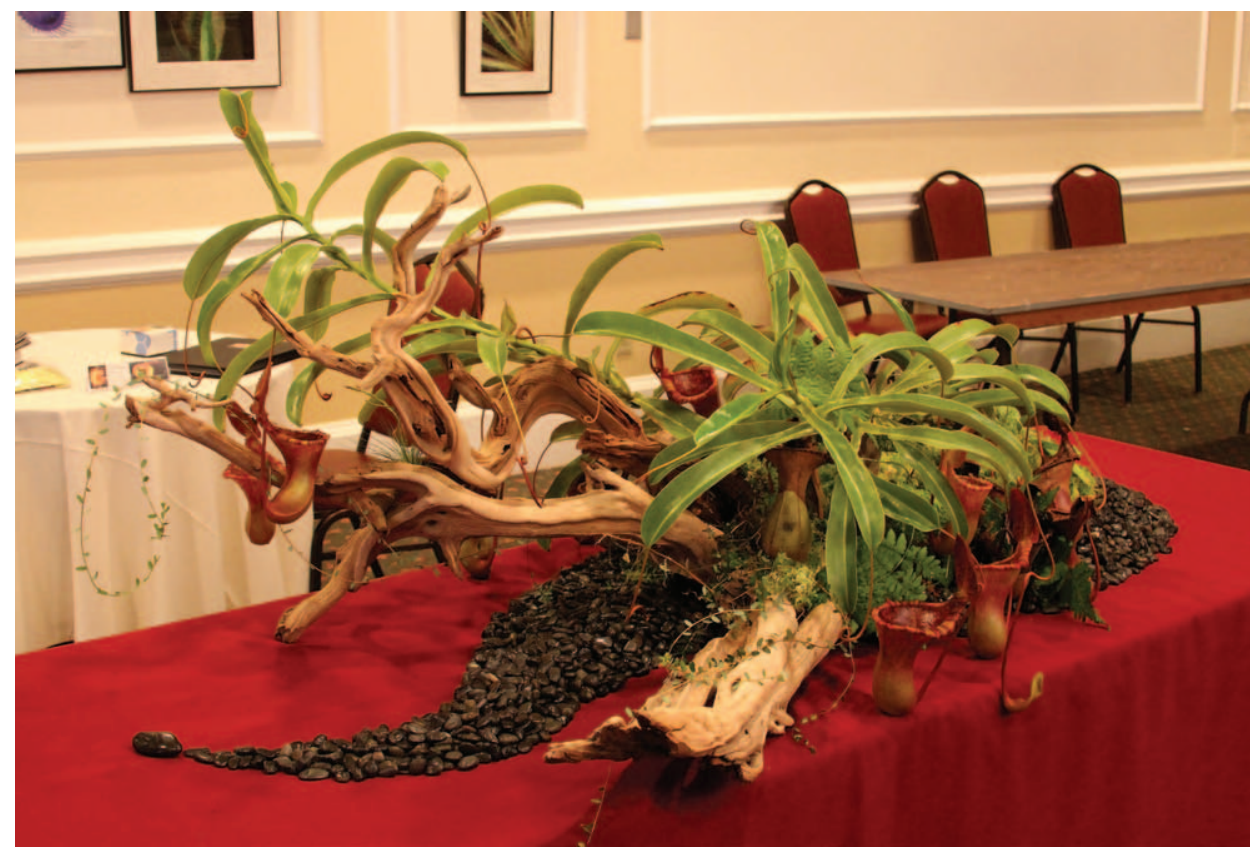

Figure 7: Nepenthes 'The Succubus' plant.

I named this plant $N$. 'The Succubus' in July 2012 because it is so deeply colored blood red, has such wicked characteristics, and with the constricted waist giving it a feminine, vampish appearance. The plant has an entrancing and demonic quality, and as it is a female, the name is particularly fitting.

-MatTHEw M. KAELIN •2703 John Street•Bellmore・NY 11710•USA・mattfromquogue@aol.com

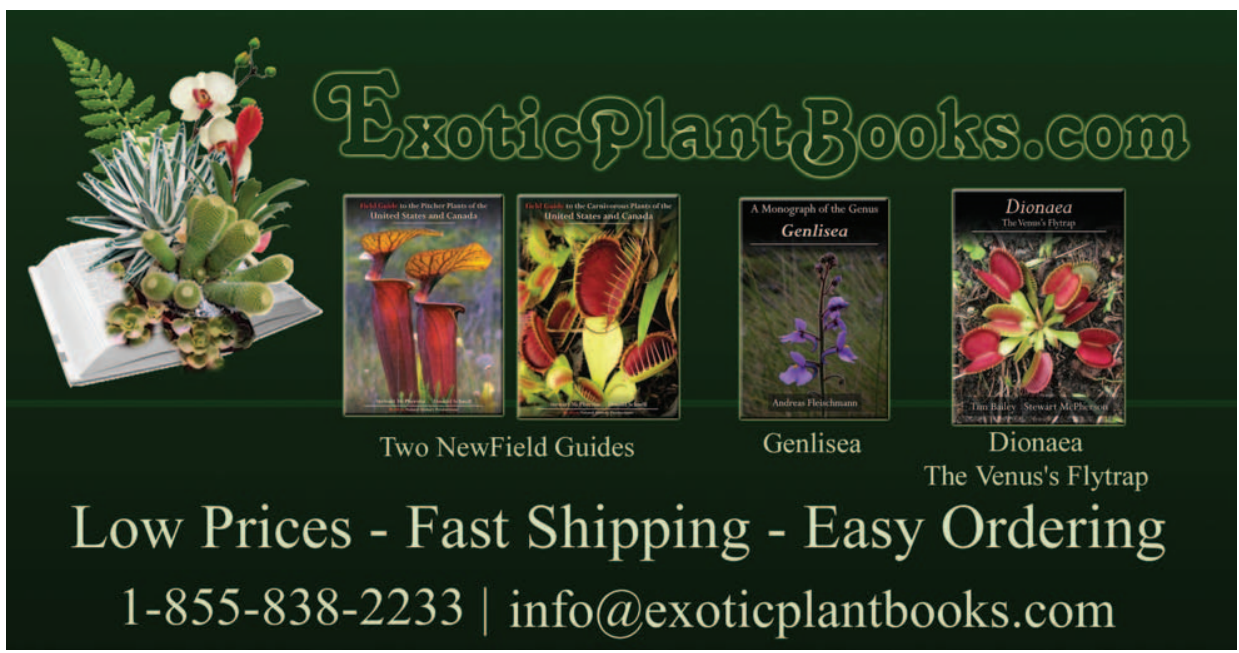




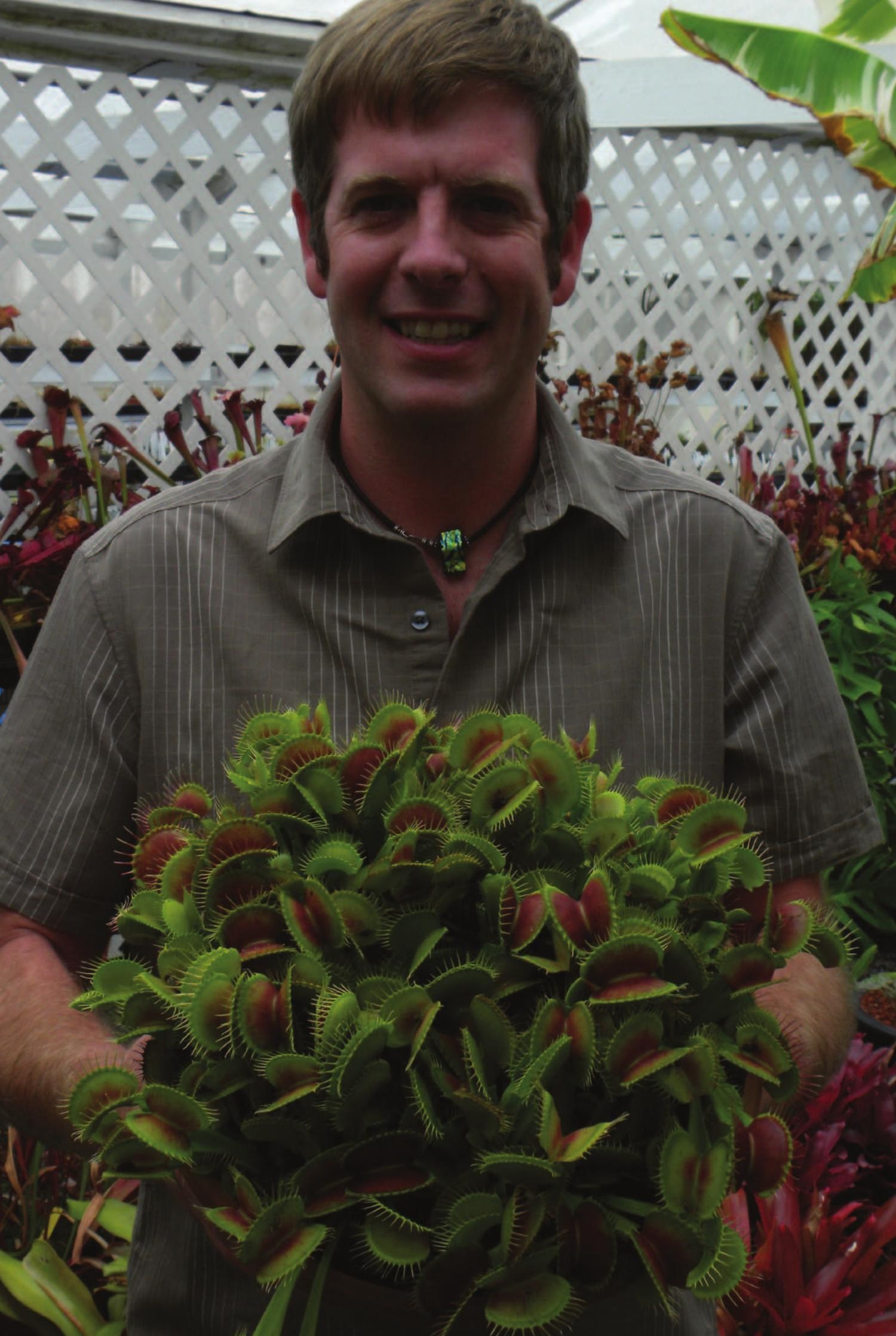




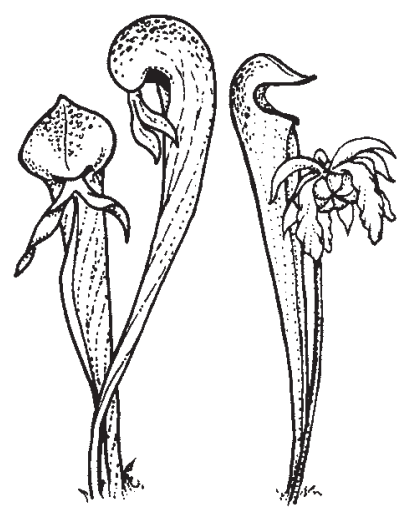

\section{CARNIVOROUS \\ PLANT \\ NEWSLETTER}

Journal of the International

Carnivorous Plant Society

www.carnivorousplants.org

Volume 42, Number 1 March 2013

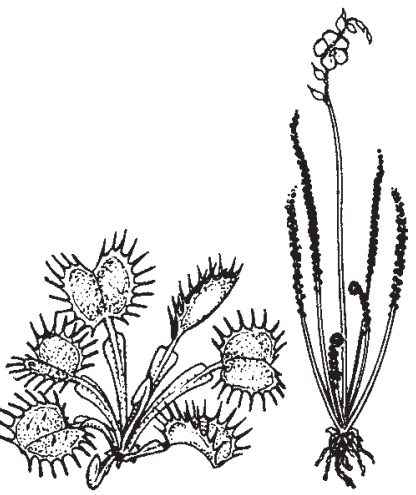

Front Cover: Colorized SEM images of terminal discs and raised heads of Drosera glanduligera snap-tentacles. Image by the Plant Biomechanics Group Freiburg and I. \& S. Hartmeyer. Article on page 4.

\section{Back Cover: The cultivar Dionaea 'Ginormous'. Photo by Damon Collingsworth. Article on page 25.}

Carnivorous Plant Newsletter is dedicated to spreading knowledge and news related to carnivorous plants. Reader contributions are essential for this mission to be successful. Do not hesitate to contact the editors with information about your plants, conservation projects, field trips, or noteworthy events. Advertisers should contact the editors. Views expressed in this publication are those of the authors, not the editorial staff.

All correspondence regarding dues, address changes and missing issues should be sent to the Membership Coordinator at the ICPS. Do not send such correspondence to the editors. Checks for subscriptions should be made to the ICPS in US funds. Dues for 2013 are $\$ 35$ for the first year of membership; renewals are $\$ 30$ per year.

ICPS, Inc.

2530 Patra Drive

Richmond, CA 94803, USA

icps@carnivorousplants.org

President

Vice President

Secretary/Treasurer

Board Member

Board Member

Board Member

Board Member

Administrator

Seed Bank Manager

CPN Editors

Managing Editor

Editor

Science Editor

Science Editor

\author{
Michael Baldwin, michael@carnivorousplants.org \\ Marcel van den Broek, marcel@carnivorousplants.org \\ Richard Myers, richard@carnivorousplants.org \\ Brian Barnes, Conservation Director, brian@carnivorousplants.org \\ Richard Nunn, richardnunn@carnivorousplants.org \\ Jan Schlauer, jan@carnivorousplants.org \\ Bob Ziemer, bob@carnivorousplants.org \\ Cindy Slezak, cindy@carnivorousplants.org \\ John Brittnacher, john@carnivorousplants.org \\ editor@carnivorousplants.org \\ Bob Ziemer \\ Barry Rice \\ Fernando Rivadavia \\ Jan Schlauer
}

Date of effective publication of the December 2012 issue of Carnivorous Plant Newsletter: 30 November 2012.

The ICPS is the International Cultivar Registration Authority (ICRA) for the names of cultivated carnivorous plants according to the International Code of Nomenclature for Cultivated Plants. Send relevant correspondence to the ICPS, Inc.

Carnivorous Plant Newsletter is published quarterly in March, June, September, and December by the ICPS, Inc., 2530 Patra Drive, Richmond, CA 94803, USA. Periodicals postage paid at Richmond, CA and additional mailing offices. Postmaster: Send address changes to ICPS, Inc., PMB 322, 1564-A Fitzgerald Drive, Pinole, CA 94564-2229, USA. Printed by Allen Press, Inc., 810 E. 10th Street, Lawrence, KS 66044. Logo and masthead art: Paul Milauskas. (C) 2013 Carnivorous Plant Newsletter. All rights reserved. ISSN \#0190-9215 